\title{
Para ve Vergiler Arasındaki Nedensellik İlişsisi: OECD Ülkeleri Üzerine Bir İnceleme
}

\author{
Ragıp YILMAZ*, Ferdi ÇELIKKAY**
}

öz

$\mathrm{Bu}$ çalışmada para arzı ile vergisel göstergeler arasındaki kısa ve uzun dönemli nedensellik ilişkileri Kartalist Yaklaşım perspektifinde incelenmektedir. Bu kapsamda para arzı (M3) ile vergiler (toplam-gelir üzerinden alınanharcamalar üzerinden alınan) arasındaki ilişkiler Euro Bölgesi dışındaki 19 OECD üyesi ülke örnekleminde 19962015 zaman diliminde ele alınmıştır. Yıllık frekanstaki değişkenler arasındaki ilişkiler Johansen Eşbütünleşme ve Vektör Hata Düzeltme Modelleri ile test edilmiştir. Elde edilen bulgular, kısa dönemde para arzından vergi hasılatına doğru tek yönlü bir nedenselliğin olduğunu ortaya koymaktadır. Uzun dönemde ise para arzı ile vergi hasılatı arasında çift yönlü bir nedensellik ilişkisi vardır. Dolayısıyla kısa dönemde para arzı, vergisel enstrümanları etkileyen ve harekete geçiren bir değişken mahiyetindedir. Uzun dönemli perspektifte iki değişken de birbirilerini etkiler hale dönüşmektedir. Sonuç olarak Kartalist Yaklaşımın görüşlerini destekler şekilde paranın yaratılmasında vergiler uzun dönemde etkili olmaktadır.

Anahtar Kelimeler: Kartalizm, Para Arzı, Vergi Hasılatı, Vektör Hata Düzeltme Modeli

JEL Sinıflandırması: E50, E51, H20

\section{The Causality Relationship between Money and Taxes: An Investigation on OECD Countries}

\begin{abstract}
In this study, it is investigated the short and long term causality relationship between money supply and taxation indicators via Chartalist Approach. To analyze this approach, the relationship between money supply (M3) and taxes (levied on total-income-expenditures) is evaluated in the 19 countries are the member of OECD except Euro Countries in 1996-2015 time period. Relations among annual variables are tested by Johansen Cointegration and Vector Error Correction Model. Findings reveal that there is a unilateral causality from money supply to tax income in the short term. However, findings indicate that there is a bilateral causality relation between money supply and tax income in the long term. Hence, money supply is a variable influencing and stimulating taxation instruments in the short term. In the long term, on the other hand, two variables reciprocally affect each other. Consequently, taxes influence money supply in the long term and this result supports Chartalist Approach ideas.
\end{abstract}

Keywords: Chartalism, Money Supply, Tax Income, Vector Error Correction Model

JEL Classification: E50, E51, H20

Geliş Tarihi / Received: 14.04.2017 Kabul Tarihi / Accepted: 20.04.2017

\footnotetext{
*Yrd.Doç.Dr., Ömer Halisdemir Üniversitesi, İ̈BF, İktisat Bölümü, ragipyilmaz78@ gmail.com

** Yrd.Doç.Dr., Eskişehir Osmangazi Üniversitesi, İ̈BF, Maliye Bölümü, ferdicelikay@gmail.com
} 


\section{GİRIŞ}

Dünya ekonomisi, her bir kırılma döneminden sonra, farklı ekonomik yapıları beraberinde getirmiştir. Kriz dönemlerine özgü bu kırılmalar, yeni teoriler etrafında yeni marka politikalar ya da eski teorilerin yenilenmiş haliyle yeniden markalaştığı politikalara da egemenlik alanı tesis etmiştir. Yeni/yeniden egemen olan marka politikalar; ülkelerin yerel özelliklerini, ekonomik-sosyal yapıyı oluşturan unsurları ve politika araçlarını da değişime uğratmıştır. Yeni teori, bir paradigma değişimi (Kuhn, 2008) anlamına gelmektedir. Artık yeni paradigma, kendinden önceki döneme kadar belirli topluluk içinde hayat alanı bulan inançları, değerleri ve teknik yöntemlerin tümünü değiştirir (Kuhn, 2008: 282). Dolayısıyla, ekonomi politikası araçları da paradigma değişiminin temsilcisi olan teori aracılığıyla egemenliğini kurmuştur. Bu egemenlik yapılanmasında, o döneme kadar hâkim olan elitler ve siyasal yapılar da değişim sürecini izlemiştir. Diğer bir ifadeyle erimeyen madeni para özelliğine sahip olan toplumsal yapılar, türler ve tutumlar (Schumpeter, 2008: 12), yeni dönemle birlikte değişime tabi olmuştur. Mesela 19. yüzyılda ortaya çıkan ekonomik kriz dünya ekonomisinde muhafazakâr bir ekonomi ve sosyal politikayı güçlendirmiştir. 1929 Buhranı, bürokrasinin egemenliğinde bir ekonomik ve siyasal yapılanmayı çıkartmıştır (Keyder, 2009: 11-12).

1970'li yıllar ise yine bir krizle, yeni bir dönem ve politik anlayışı hâkim kılmıştır. Bu dönemde yaşanan petrol krizleri ve stagflasyon olgusu ile Keynezyen ekonomi ve Refah Devleti'ne yönelik uygulamalar ortadan kalkmıştır. Ekonomi politikaları, Monetarist ve Rasyonel Bekleyişler hipotezlerine dayalı paradigma değişiminin temsilcisi olmuştur. Neoliberal olarak isimlendirilen bu yeni dönem, ekonominin işleyişini piyasa kurumlarını daha fazla ayrıştırmak yoluyla yürütmeyi hedeflemiştir (Amable, 2011). Böylece Keynezyen dönemde geçerli olan vergilerin ve kamu harcamalarının yeniden dağıtım politikaları, uluslararası sermaye hareketleri üzerindeki kontroller, ekonomik düzenlemeler, kamusal mal ve hizmetlerin belirlenmesi, aktif para ve maliye politikaları uygulamaları paradigma değişimi sonucunda önemini kaybetmiştir (Centeno ve Cohen, 2010; Gwartney, Hall ve Lawson, 2010; Miller ve Holmes, 2011).

Bütün bu politik tercihlerin yerine Neo-liberalizm, enflasyon ile mücadeleye öncelik verilmiştir (Centeno ve Cohen, 2012: 319). Enflasyonu kontrol edip fiyat istikrarını sağlamaya yönelik politikalar da zaman tutarsızlığı problemini (time-inconsistency problem) (Kydland ve Prescott, 1977; Barro ve Gordon, 1983) çözmeyi birincil amaç edinmiştir. Diğer bir ifadeyle, yeni paradigmanın bilimsel devrimiyle enflasyonu kontrol altına almak amaçlanmış ve işsizlik ikincil bir sorun olarak görülmüş̧ür. Bununla birlikte siyaset ve ideolojiler, gelecek tasavvurunda önemini kaybetmiştir. Bunun yerine geleceği belirgin hale getirmek ve kontrol etmek, ekonomi politikası araçlarının üzerine yüklenmiştir. Teorinin belirlediği kurallar, gerçek hayatın akış seyrini belirlemeye başlamıştır (Chari ve Kehoe, 2006). Paradigma değişimi etrafinda yeni ekonomi politikaları, yeni bir 'hayali cemaat' (Anderson, 2011) oluşturmaya yönelmiştir. Bunu desteklemek için de teknolojinin ve sermaye hareketlerinin yardımıyla, yeni teoriyi dünya ekonomisinde etkinleştirmesi sağlayacak yeni bir 'gelenek icat edilmiştir' (Hobsbawm ve Ranger, 2006). Rasyonel düşünceyle şekillendirilen ve yönlendirilen cemiyet (Tönnies, 2000: 203), bu sayede teoriye uygun davranmaya teşvik edilmiştir. Böylece zaman tutarsızlığı problemi ortadan kaldırılırken, gelecek de kontrol altına alınmaya çalışıldı.

Geleceğin belirsizliğini azaltmaya, zaman tutarsızlığı problemini ortadan kaldırmaya ve fiyat istikrarını sağlamaya yönelik politikaların temel aracı da para olmuştur. Nötr şekilde değerlendirilen para, bireyin de özgürleşmesini teşvik etmiştir. Bireyler özgürleşirken kendi hayatları da nesneleşmeye başlar. Böylece birey, para aracılığıyla başka kişilerle artan bağımlılık ilişkisine girmeye zorlanır (Jung, 1995: 58). Bu nedenle para her şeyin ölçüsü haline gelmiştir. Toplumda "şeyler" arasındaki geçişi para hızlandırırken, bu şeyler aynı zamanda paranın bağımlısı olmuştur (Jung, 1995: 63). Öte yandan para soyut iktisadi bir değeri temsil ederken, 
elle tutulduğu dönem içinde en kısa ömürlü nesne olmasına karşılık, karşısındaki diğer kavramlar/olgular mukayese edildiğinde kayıtsızlık ve denge noktası olması nedeniyle en uzun ömürlü nesnedir. Bu yönüyle toplum içinde hareket ederken, mübadele işlevi ile toplumsal ağı ören bir örümcek haline gelir (Frisby, 2005: 34-35).

Örümcek ağı şeklinde toplumsal ilişkileri çevreleyen para, bu ilişkiyi, doğal bir şekilde mi yerine getirmekte; yoksa bu toplumsal ilişkileri yasal yollarla bir düzene koymaya çalışan devlet tarafından yaratılmasıyla $\mathrm{m}$ y yapmaktadır? $\mathrm{Bu}$ ise paranın nötr olduğunu ve doğal yollardan ortaya çıktığını iddia eden Metalist Yaklaşım ile toplumsal ilişkilerin ve bu ilişkileri yönlendiren devletin yarattığı bir olgu olduğunu iddia eden Kartalist Yaklaşım tartışmasını beraberinde getirir. $\mathrm{Bu}$ çalışmanın amacı bu tartışma perspektifinde para arzı ile vergisel göstergeler arasındaki kısa ve uzun dönemli nedensellik ilişkilerini Euro Bölgesi dışındaki OECD ülkeleri örnekleminde irdelemektir. Çalışmada ilk olarak paranın yaratılmasında Metalist/Kartalist tartışması ele alınmıştır. Daha sonra bu tartışma, Yılmaz ve Çelikay (2017) tarafindan Türkiye'de zaman serisiyle test edilen ampirik bulgular perspektifinde genişletilerek OECD ülkeleri nezdinde Vektör Hata Düzeltme Modelleri ile birlikte test edilmiştir. Bu çalışma ile heterodoks yaklaşım olan Kartalist Yaklaşımın paranın vergiler yoluyla yaratıldığı yolundaki düşüncesi test edilerek, literatüre amprik yönüyle katkı sağlanmıştır.

\section{NÖTR PARA-SIYYASI PARA: METALISTT-KARTALİST TARTIŞMASI}

Tanımı ve kaynağı itibariyle para, yüzyıllardır ekonomistlerin üzerinde uğraşı sarf ettiği konulardan biridir. Nitekim 19. yüzyılda Newtonyan yaklaşım, 20. yüzyılda ise Einstanyan veya Rölativisit yaklaşım paranın tanımlanmasında daha baskındır (Bordo ve James, 2006). Ayrıca Ortodoks iktisada göre para, işlem maliyetlerini azaltmak amacıyla mübadele esnasında doğan, dışsal bir enstrümandır. Dolayısıyla paranın yegane fonksiyonu değişim aracı olmasıdır. Bunun yanında Heterodoks yaklaşım ise parayı endojen bir enstrüman olarak betimler. Bu yaklaşıma göre para ve banka mevduatları talebe bağlı olarak yaratılır.

Ortodoks iktisat parayı eksojen bir araç olarak değerlendirir. Para, işlem maliyetlerini azaltmak amacıyla değiş-tokuş esnasında ortaya çıkan bir nesnedir. Değişim aracı olma özelliği dışında herhangi bir fonksiyonu yoktur. Heterodoks yaklaşım ise paranın endojen bir şekilde yaratıldığını iddia eder. Özel para çoğunlukla da banka mevduatları, talebe bağlı olarak yaratılır. Bundan dolayı da nakit olarak bankaya yatırılması ya da bankadan kredi çekilmesi yoluyla bu paranın yaratılması söz konusu olur. Diğer bir ifadeyle krediler mevduatların yaratılmasını sağlar (Wray, 2002: 25).

Para kaynağı üzerindeki tartışmalar zamanla kurumsal değişim geçirmiştir. İlk aşamada değerli maden parasından fiyat paraya doğru evrilmiştir. Bu aşamada altın veya gümüş gibi değerli madenler para olarak tanımlanmıştır. Daha sonra ise fiyat para sistemi paranın ne olduğunun tartışmasında öne çıkmıştır. Her iki aşamada da somut ve elle tutulabilir nesneler para olarak değerlendirilmiştir. Son dönemde ise para, teknolojik ve finansal gelişmelere uyum sağlamıştır. Somut olmayan, elle tutulamayan nesneler de para olarak kabul edilmeye başlanmıştır. Böylece para şekil değiştirmesine karşılık, ne olduğu ve nasıl ortaya çıktığına dair tartışmalar sürekli gündemde kalmıştır. Bu tartışmalar iki görüş etrafinda şekillenmektedir. Bunlardan birisi Metalist/Mengeryen Yaklaşım olup, paranın piyasa tarafından yaratıldığını ve doğal olarak ortaya çıktığını öne sürer. Diğer yaklaşım ise paranın siyasal kurumlar tarafından yaratıldığını iddia eden Kartalist (bölünebilir para) (Weber, 1995: 122) Yaklaşımdır.

Metalist Yaklaşım ilk olarak Menger (2009: 189-193) tarafından ortaya atılmıştır. Bu yaklaşım paranın kullanım değerine odaklanmaktadır. Günlük hayattaki uygulamalar, alışkanlıklarla birlikte, değiş-tokuş sırasında paranın kullanım değerini belirler. Toplumdaki fertler, kendi aralarında değiş-tokuş faaliyetinde bulunurken, değerli madene dayalı paranın 
kullanım değerine göre hareket ederler. Değiş-tokuş faaliyetinin yerine getirilebilmesi için, bireylerin istek ve arzuları aynı ve benzer olmalıdır. Bunun için de bilgi akışının şeffaf olması, mala ait bilginin herkes tarafindan elde edilebilmesi gerekir. Ancak toplum içindeki her birey tam bilgiye sahip olamadığından alışkanlıklar ve pratiğe dayalı olarak ortaya çıkan para, bu alışkanlıklar ve pratik aracılığıyla değiş-tokuş işlemini kolaylaştırır. Bunun sonucunda para, herhangi bir siyasi otoritenin kararına, yaptırım gücüne bağlı olmadan doğal bir şekilde meydana çıkar. Diğer bir ifadeyle değiş-tokuş içerisindeki ticari mallar, siyasal yapılardan uzak, kendiliğinden para şeklinde işlem görür. Dolayısıyla para, devlet-birey tarafından ortaya çıkartılan yapay bir nesne olmaz, zaman ve mekândan bağımsız bir şekilde ortaya çıkar.

Kullanım değerini öne çıkartan Menger'e karşılık Aristoteles'e dayandırılan Metalist Yaklaşım ise parayı iki temel yapı üzerinden tanımlar. Bu tanımlamada paranın ilk olarak değişim aracı olma özelliğine vurgu yapılır. Paranın değeri ise değerli maden tarafindan tayin edilir. Böylece paranın değişim özelliği aynı zamanda değerini de belirler. Bu nedenle para, sadece mal ve hizmet işlemlerinde aracılık hizmeti görür (Schumpeter, 1954: 62-63). Dolayısıyla para Adam Smith'in vurguladığı şekilde sadece ticaretin evrensel aracı olur (Cesarano, 1995:447). Yani para; işlem maliyetlerini azaltan, miktarı sadece Merkez Bankası tarafindan belirlenen ve eksojen olarak yaratılan nötr bir değiş-tokuş aracıdır. Bu özellikleri nedeniyle paranın ekonomik hayat üzerinde sadece enflasyonla doğrudan ilişkisi olan bir nesnedir. Kartalist Yaklaşım ise paranın daha çok sosyal fonksiyonuna ${ }^{1}$ vurgu yapar ve ticari bir mal olma özelliğini göz ardı eder. Bununla birlikte paranın toplumsal olma özelliğiyle hesap birimi olmasını öne çıkartır. Ayrıca para arzı bankalar aracılığıyla endojen şekilde belirlenir. Bunun için de para Merkez Bankası tarafından yaratılan bir nesne olmaz. Merkez Bankaları sadece faiz oranlarını etkiler. Bundan dolayı da para nötr bir nesne değildir ve enflasyon-para arasında bir ilişki yoktur (Wray, 2002: 23).

Bu özelliklerinin yanı sıra para bir borç ilişkisine dayalı olarak da ortaya çıkabilir (Bell ve Henry, 2001:219). Böylece para, biçim özelliğini hesap paradan alırken, borçları, fiyat listelerini ve genel satın alma gücünü de temsil eder. Nitekim hesap birimi olma özelliğini teslim edildiğinde borç sözleşmeleriyle, yerine getirildiğinde fiyat sözleşmeleriyle ve elde tutulduğunda satın alma gücüyle kazanır. Değiş-tokuş aracı olmanın ötesinde, genel satın alma gücü, paranın temsil kabiliyetini arttırır. Dolayısıyla takas evresinden çıkılıp, hesap para ile ilişkilendirilen nesne toplum içinde para olarak kabul edilir (Keynes, 2012:3), toplumsal bir değer birimi haline gelir (Wray, 2012: 8).

Para devlet ile ilişkilendirildiğinde kefaret ödemeleri de neyin para olarak toplumda kabul göreceğini belirler. Daha sonraki dönemlerde ise diğer kamu gelirleri de (vergiler, harçlar, resimler, kira ve faiz ödemeleri, parafiskal gelirler, para ve vergi cezaları) paranın ne olduğunun tanımlanmasında etkili olmuştur. Bu durum aynı zamanda gelir elde eden otoritenin egemenlik gücündeki biçim değişimiyle paranın gelişimi arasında bir paralellik olduğunu gösterir. ${ }^{2}$ Diğer taraftan para, Kartalist Yaklaşıma göre vergiye dayalı (tax-driven approach) (Wray, 2002: 28)

\footnotetext{
${ }^{1}$ Kartalist düşüncede para değişim aracı olmanın ötesinde değerlendirilir. Zelizer (1989)'e göre para, doğasında toplumsal ilişkinin var olduğu bir olgudur. Ingham (2000: 19) ise paranın ekonomik aktörler ve bu aktörler ile para otoritesi arasındaki toplumsal ilişkilere dayandığını savunur. Bunun yanında Neale (1976:4) bütün paraların, ekonomik ve toplumsal ilişkiler sisteminin geniş bir parçası olduğunu savunur. Paraya ilişkin bu tanımlamalar, onu sosyal bir ilişki içerisinde ele alır. Ayrıca Hudson (2004)'un savunduğu gibi, para mabetlerde ve saraylarda bir hesap birimi olarak yaratılmıştır. Diğer bir ifadeyle para ilk defa erken dönem bürokrasisi tarafindan icat edilmiştir.

2 Otoritenin gelirini oluşturan bu ödemeler, aynı zamanda sürekli gelişen kurumsal düzenlemelerin de bir yansımasıdır. Tapınakların yönetimde hâkim olduğu yapılardan sarayların otoriteyi temsil ettiği yapılara, feodal toplum yapısından demokratik yollarla iktidara gelen seçilmiş hükümetlere doğru bir siyasal gelişim çizgisi de bu süreç içinde oluşan gelişim aşamaları olarak değerlendirilebilir (Wray, 2002: 28, Goodhart, 1998:413).
} 
olarak devlet parası (Knapp, 1924) şeklinde de yaratılabilir. Diğer bir ifadeyle para, devlet tarafindan belirlenen bir nesnedir. Devlet tarafından belirlenmesini sağlayan şey ise sözleşmeler ve tekliflerin, kanunlar veya adetler tarafından şekillendirilmesidir. Böylece devlet, hem hesap parasını belirler hem de sözleşmeler ve fiyat listelerinin karşılığında neyle ödeme yapılacağını da tanımlar. Ödemenin yapılmasında yasal otorite devreye girmiş olur (Keynes, 2012: 4). Bu sayede para hesap birimine dayalı olarak otorite tarafından nominal değer ile bir nesnenin tanımlanması şeklinde ortaya çıkar. Devletin tedavüle sokmasıyla kendine fiili bir hayat alanı bulan para, siyasi otoritenin konvertible olmayan borcunun temsilcisi olur (Gnos ve Rochon, 2002: 46). Bundan dolayı paranın yaratılmasında değişim işlemi gerekli koşul değildir. Bunun yerine cezai işlemler ve/veya vergiler para olacak nesnenin belirlenmesinde öncül rol oynar (Peacock, 2003: 208-209).

Para ile kamu gelirlerinin içerisinde en önemli paya sahip olan vergiler arasında çok yönlü ilişki söz konusudur. Nihayetinde üretim, ulaşım, servet, ticari mallar gibi mali kaynaklar para olmadan vergilendirilendirmesi söz konusu olmamakta, sadece malların dağıtım ve teslimi yapılabilmektedir. Para ise dolayız (gelir ve servet) ve dolaylı (harcama ve işlemler) vergilerinin toplanmasını kolaylaştırır. Böylece mal ve emek değeri üzerindeki vergilerle mal dengesine ulaşılır. Bu denge ile hem kamu kesiminin harcamalarına kaynak bulunur, hem de kamunun işlem maliyetleri azaltılır. Ayrıca baz paraya olan talep, vergiye dayalı para ile artar. Devletin paranın yaratılmasıyla sağladığı senyoraj geliri, mali pozisyonunu da güçlendirir. Bunun nedeni bir yandan vergi toplama imkanının genişlemesi diğer yandan da artan para talebiyle senyoraj gelirinin doğmasıdır (Goodhart, 1998: 416).

Öte yandan piyasaya ne miktarda paranın sürüleceği toplanan vergi hasılatıyla ilişkilidir. Toplanan vergi hasılatı kadar para piyasaya sürülmelidir. Zira vatandaşlardan toplanan vergi kadar para miktarının tedavüle sokulması zorunludur. Ancak bu ilişkinin sağlanması için bütçe denkliği gerekli koşuldur. Kamu hizmetleri yapılacak harcamalar, vergiler ile yerine getirilirken bu hizmetlerle vatandaşlara fatura karşılığı ödeme yapılmış olur. Böylece para, vatandaşların kullandığ 1 devletin de tedavüle soktuğu kimliğine kavuşur. Bunun için de tedavüle sokulan para miktarı devletin vergi talebini aşmamalıdır (Peacock, 2003: 210-211).

Bütün bu özellikleriyle para, Kartalist Yaklaşıma göre nötr değildir, nötr olsa dahi reel bir etkiye sahiptir. Değişim aracı olma özelliğini, sadece kaynakların devlete aktarılmasında elde eder. Diğer yandan para, sadece piyasanın karşılıklı ticaretten fayda sağlanan bir yer olmasını sağlamaz, borçlar aracılığıyla elde edilen kazançların bir aracısı olmasını tesis eder. Böylece piyasa borçlar aracıllğıyla parasallaşmış bir kurum olur (Wray, 2002: 29-30). Bunun yanı sıra devlet de kendisine karşı yükümlülükleri tespit eder. Paranın sosyal bir hesap birimi olmasıyla da kendisine karşı olan yükümlülükleri hesaplar. Para hesap birimi olarak belirlendiğinde, paranın yaratılmasında piyasalara ihtiyaç duyulmaz. Tersine hesap birimi olan para piyasaların oluşmasını sağlar. Ayrıca hesap birimi olan para otorite tarafından tesis edileceği için devlet, kendisine yapılacak ödemeleri de isimlendirmiş olur. Bu da herhangi bir nesneye nominal değer atfedilmesi demektir (Wray, 2002: 28). Dolayısıyla paranın yaratılmasındaki temel rolü piyasa değil devlet üstlenir.

\section{METODOLOJI}

Çalışmada 19 OECD üyesi ülkenin ${ }^{3}$ 1996-2015 yıllarını kapsayan döneme ilişkin para arzı ve vergi hasılatı verileri kullanarak, değişkenler arasındaki nedensellik ilişkileri Kartalist

\footnotetext{
${ }^{3}$ Söz konusu ülkeler “Avusturalya, Kanada, Şili, Çek Cumhuriyeti, Danimarka, Macaristan, İzlanda, İsrail, Japonya, Güney Kore, Meksika, Hollanda, Norveç, Polonya, İsveç, İsviçre, Türkiye, İngiltere, ABD” dir.
} 
Yaklaşım perspektifinde ele alınmakta olup, bu amaç doğrultusunda panel veri analizi yöntemlerinden yararlanılmaktadır. Genel olarak panel veri analizi ülke, bölge, şehir ya da hane halkı gibi yatay kesit birimlerinin belirli bir zaman dilimindeki etkileşimlerini eşanlı olarak analiz sürece katan bir yöntemdir. Böylece hem zaman hem de yatay kesit boyutu itibariyle analiz süreci daha da derinleştirilerek araştırmanın temsil kabiliyeti arttırılabilmektedir.

Değişkenler arasındaki uzun dönemli nedensellik ilişkisini tespit edebilen Vektör Hata Düzeltme Modeli özellikle aynı düzeyde durağan hale gelen ve uzun dönemde aralarında eşbütünleşik ilişki bulunan verilere uygulanabilmektedir. Bu kapsamda çalışmada öncelikle verilerin durağanlıkları Levin, Lin\&Chu (LLC) ile Fisher-ADF ve Fisher-PP panel birim kök testleri ile sınanmıştır. LLC testi birim kök varlığının panel geneli itibariyle ele alınmasını sağlarken, Maddala ve Wu (1999) ile Choi (2001) tarafından geliştirilen Fisher-ADF ile FisherPP testleri ise panel içerisindeki her bir yatay kesit birimi itibariyle durağanlık değerlendirmesi yapabilmektedir.

Serilerin düzeyde durağan olmadığı fakat aynı dereceden farkları alındığında durağan hale geldiği belirlendikten sonra bu kez ele alınan değişkenlerin uzun dönemde birlikte hareket edip etmedikleri saptanmalıdır. Bu doğrultuda çalışmada Johansen Fisher Eşbütünleşme Testi kullanılmıştır. Maddala ve Wu (1999) tarafından geliştirilen bu test, birim bazlı Johansen eşbütünleşme testinin panel veri setleri için geliştirilmiş bir versiyonudur. Johansen (1988) eşbütünleşme testi, "İz (Trace) İstatistiği” ve "En Yüksek Öz Değer İstatistiği” olmak üzere iki alt bileşenden oluşmaktadır. İz İstatistiğini belirleyebilmek bağlamında geliştirilen testin boş hipotezinde eşbütünleşme rankı (r) kadar eşbütünleşme ilişkisi irdelenmektedir. Matematiksel olarak İz Testi;

$\operatorname{LR}_{\text {Trace }}(\mathrm{r} / \mathrm{k})=-\mathrm{T} \sum_{\mathrm{i}=\mathrm{r}+1}^{\mathrm{n}} \log \left(1-\Lambda_{\mathrm{i}}\right)$

olarak formüle edilmektedir. En yüksek Öz Değer istatistiğini belirleyecek alt testte ise yine boş hipotez olarak (r) kadar eşbütünleşme rankı aranmakta, alternatif hipotezinde $\mathrm{r}+1$ kadar eşbütünleşme ilişkisinin varlığı sınanmaktadır. Bu bağlamda Maksimum Öz Değer Testi;

$\operatorname{LR}_{\text {Max }}(\mathrm{r} / \mathrm{r}+1)=-\operatorname{Tlog}\left(1-\Lambda_{\mathrm{r}+1}\right)$

şeklinde belirtilmektedir. Bunun yanında Johansen Fisher Eşbütünleşme Testinde ise analiz bulguları, her bir birim için ayrı ayrı uygulanan iki testin olasılık değerlerinin toplulaştırılmasıyla elde edilmekte, eşbütünleşme istatistiği;

$-2 \sum_{i=1}^{N} \log \left(\pi_{i}\right)$

şeklindedir.

Eşbütünleşik ilişki içerisindeki değişkenlerin uzun dönemli nedensellik ilişkileri Vektör Hata Düzeltme Modelleri (VECM) ile tespit edilebilmektedir. VECM için regresyon eşitliği;

$$
\begin{aligned}
& \Delta Y_{i, t}=\propto_{1, t}+\sum_{p=1}^{n} \propto_{11 i, p} \Delta Y_{i, t-p}+\sum_{p=1}^{n} \propto_{12 i, p} \Delta X_{i, t-p}+\theta_{1, i} e c t_{i, t-1}+u_{1 i, t} \\
& \Delta X_{i, t}=\propto_{2, t}+\sum_{p=1}^{n} \propto_{21 i, p} \Delta X_{i, t-p}+\sum_{p=1}^{n} \propto_{22 i, p} \Delta Y_{i, t-p}+\theta_{2, i} e c t_{i, t-1}+u_{2 i, t}
\end{aligned}
$$

dir. Burada hata terimini gösteren "ect" nin negatif ve istatistiksel olarak anlamlı olması, ele alınan değişkenler itibariyle uzun dönemde nedensellik ilişkisini yansıtmaktadır. Değişkenler arasındaki kısa dönemli ilişkiler ise Wald Testi ile belirlenebilmektedir. Wald Testinde bağımlı değişkeni etkileme açısından, bağımsız değişkenler arasında istatistiksel açıdan anlamlı bir farklılığın olmadığı boş hipotezi değerlendirilmektedir. Bu çerçevede test sonuçları $\mathrm{F}$ istatistiği sonuçlarına bakılarak reddedilirse, bağımlı ve bağımsız değişken arasında kısa dönemde de Granger nedenselliğin olduğu tespit edilmektedir.

Çalışmada para arzı ile vergi hasılatı arasındaki ilişkileri irdeleyebilmek amacıyla; 
$\mathrm{H}_{1}$ : Para arzı ile toplam vergi hasılatı arasında nedensellik ilişkisi vardır.

$\mathrm{H}_{2}$ : Para arzı ile gelir üzerinden alınan vergiler arasında nedensellik ilişkisi vardır.

$\mathrm{H}_{3}$ : Para arzı ile harcamalar üzerinden alınan vergiler arasında nedensellik ilişkisi vardır.

şeklinde üç ana hipotez geliştirilmiştir. Bu hipotezlerin geliştirilmesi sürecinde kurgulanan VEC Modelleri ise;

$\mathrm{H}_{1}$

$$
\begin{gathered}
\Delta \ln M 3_{i, t}=\propto_{1, t}+\sum_{p=1}^{n} \propto_{11 i, p} \Delta \operatorname{lnM} 3_{i, t-p}+\sum_{p=1}^{n} \propto_{12 i, p} \Delta \operatorname{lnTVH}_{i, t-p}+\Theta_{1, i} e c t_{i, t-1}+ \\
u_{1 i, t}(6)
\end{gathered}
$$

$$
\begin{gathered}
\Delta \operatorname{lnTVH}_{i, t}=\propto_{2, t}+\sum_{p=1}^{n} \propto_{21 i, p} \Delta \operatorname{lnTVH}_{i, t-p}+\sum_{p=1}^{n} \propto_{22 i, p} \Delta \operatorname{lnM} 3_{i, t-p}+\theta_{2, i} e c t_{i, t-1}+ \\
u_{2 i, t}
\end{gathered}
$$

$\mathrm{H}_{2}$

$$
\Delta \ln M 3_{i, t}=\propto_{1, t}+\sum_{p=1}^{n} \propto_{11 i, p} \Delta \operatorname{lnM} 3_{i, t-p}+\sum_{p=1}^{n} \propto_{12 i, p} \Delta \operatorname{lngAV} \operatorname{Lit}_{i, t-p}+\theta_{1, i} e c t_{i, t-1}+
$$

$$
\begin{gathered}
\Delta \operatorname{lnGAV}_{i, t}=\propto_{2, t}+\sum_{p=1}^{n} \propto_{21 i, p} \Delta \operatorname{lnGAV}_{i, t-p}+\sum_{p=1}^{n} \propto_{22 i, p} \Delta \ln \mathrm{M}_{i, t-p}+\theta_{2, i} e c t_{i, t-1}+ \\
u_{2 i, t}
\end{gathered}
$$

$\mathrm{H}_{3}$

$$
\begin{gathered}
\Delta \ln M 3_{i, t}=\propto_{1, t}+\sum_{p=1}^{n} \propto_{11 i, p} \Delta \operatorname{lnM} 3_{i, t-p}+\sum_{p=1}^{n} \propto_{12 i, p} \Delta \operatorname{lnHAV} V_{i, t-p}+\theta_{1, i} e c t_{i, t-1}+ \\
u_{1 i, t}
\end{gathered}
$$

$$
\begin{gathered}
\Delta \operatorname{lnHAV} V_{i, t}=\propto_{2, t}+\sum_{p=1}^{n} \propto_{21 i, p} \Delta \operatorname{lnHAV}_{i, t-p}+\sum_{p=1}^{n} \propto_{22 i, p} \Delta \operatorname{lnM} 3_{i, t-p}+\theta_{2, i} e_{2 i, t}(11)
\end{gathered}
$$

şeklindedir. Burada yer alan eşitliklerde $\Delta$ fark terimini, "lnM3" geniş tanımlı para arzının doğal logaritmasını, "InTVH" kişi başına düşen vergi hasılatının doğal logaritmasını, "InGAV" kişi başına gelir üzerinden alınan vergilerin doğal logaritmasını, "InHAV" kişi başına harcamalar üzerinden alınan vergilerin doğal logaritmasını, "i” 19 OECD üyesi ülkeyi, "t" 1996-2015 dönemindeki her bir yıl1, "n" belirlenmiş optimal gecikme uzunluklarını, "ect" hata düzeltme terimini ve " $u$ " hata düzeltme terimini göstermektedir. Aşağıda çalışmanın hipotezleri ve bu hipotezler çerçevesinde geliştirilen modellerin sınanması amacıyla yararlanılan ampirik analiz ve elde edilen bulgulara yer verilmektedir. 


\section{AMPÍRIKK BULGULAR}

Çalışmada para arzı ile vergisel göstergeler arasındaki kısa ve uzun dönemli nedensellik ilişkilerini ortaya koyabilmek amacıyla 19 OECD üyesi ülkenin 1996 ile 2015 yıllarına ilişkin geniş tanımlı para arzı (M3) ${ }^{4}$ ile "toplam", "gelir üzerinden alınan" ve "harcamalar üzerinden alınan" vergi hasılatı verileri kullanılmıştır. Verilerin derlenmesi sürecinde OECD, Dünya Bankası ve IMF'in veri tabanlarından yararlanılmıştır. Çalışmada örneklem olarak Euro Bölgesi dışında kalan OECD üyesi ülkeler esas alınmış, ele alınan değişkenler itibariyle 1996 yılı öncesine ait dengeli panel seti oluşturacak veri olmaması nedeniyle zaman aralığ1 1996-2015 dönemi ile sınırlandırılmıştır. Bunun yanında vergi hasılatı değişkenlerinden nüfusun etkilerini arındırabilmek ve reel değişkenlerle analiz yapabilmek amacıyla Dolar karşılığı kişi başına düşen değerler esas alınmıştır. Ayrıca analiz sürecinde normallik koşulunun sağlanabilmesi için ele alınan dört değişkenin de doğal logaritmaları alınmıştır. Yararlanılan değişkenlere ilişkin açıklamalar Tablo 1'de yer almaktadır. ${ }^{5}$

\section{Tablo 1: Çalışmada Kullanılan Veriler}

\begin{tabular}{|c|c|c|}
\hline $\begin{array}{l}\text { Değișkenin } \\
\text { Türü }\end{array}$ & Kodu & Açıklaması \\
\hline Para Arzı & $\ln \mathrm{M} 3$ & $\begin{array}{l}\text { OECD (2017)’nin geniş tanımlı para arzı “2010 yılı = } 100 ” \text { olacak } \\
\text { şekilde mevsimsellikten arındırılarak hesapladığı reel para arzı esas } \\
\text { alınmıştır. }\end{array}$ \\
\hline $\begin{array}{l}\text { Toplam Vergi } \\
\text { Hasılatı }\end{array}$ & $\operatorname{lnTVH}$ & $\begin{array}{l}\text { 1996-2015 döneminde yıllık kişi başına toplanan toplam vergi hasılatının } \\
\text { (Dolar) doğal logaritmasıdır. }\end{array}$ \\
\hline $\begin{array}{l}\text { Gelir } \\
\text { Üzerinden } \\
\text { Alınan Vergi } \\
\text { Hasılatı }\end{array}$ & $\operatorname{lnGAV}$ & $\begin{array}{l}\text { 1996-2015 döneminde yıllık kişi başına gelir üzerinden alınan vergilerin } \\
\text { (Gelir ve Kurumlar Vergileri) (Dolar) doğal logaritmasıdır. }\end{array}$ \\
\hline $\begin{array}{l}\text { Harcamalar } \\
\text { Üzerinden } \\
\text { Alınan Vergi } \\
\text { Hasılatı }\end{array}$ & $\operatorname{lnHAV}$ & $\begin{array}{l}\text { 1996-2015 döneminde yıllık kişi başına harcamalar üzerinden alınan } \\
\text { vergilerin (Mal ve Hizmet Üzerinden Alınan Vergiler) (Dolar) doğal } \\
\text { logaritmasıdır. }\end{array}$ \\
\hline
\end{tabular}

Analiz sürecinde öncelikle kullanılan değişkenlerin durağanlıkları sınanmıştır. $\mathrm{Bu}$ bağlamda Levin, Lin ve Chu ile Fisher (ADF ve PP) birim kök testlerine ilişkin sonuçlar Tablo 2'de yer almaktadır.

\footnotetext{
${ }^{4}$ OECD’nin M1 ve M3 şeklinde yayımladığı para arzı istatistiklerinden toplumdaki parasal ilişkileri daha detaylı ve kapsamlı bir şekilde gösteren geniş tanımlı M3 para arzı kullanılmıştır.

${ }^{5}$ Ampirik analiz sürecinde yararlanılan testler Eviews-8 paket programıyla gerçekleştirilmiştir.
} 
Tablo 2: Birim Kök Testlerine İlişskin Sonuçlar

\begin{tabular}{lrrrr}
\hline & lnM3 & LnTV & lnGAV & $\ln H A V$ \\
\hline $\mathrm{I}(0)$ & & & & 5.90631 \\
\multirow{2}{*}{ Levin,Lin\&Chu } & 12.2847 & 6.58360 & 4.92340 & $(1.0000)$ \\
& $(1.0000)$ & $(1.0000)$ & $(1.0000)$ & 2.77704 \\
ADF - Fisher & 3.16980 & 2.02593 & 3.37445 & $(1.0000)$ \\
& $(1.0000)$ & $(1.0000)$ & $(1.0000)$ & 2.33279 \\
PP - Fisher & 1.83274 & 2.01220 & 3.46299 & $(1.0000)$ \\
\hline I(1) & $(1.0000)$ & $(1.0000)$ & $(1.0000)$ & $-12.1266^{*}$ \\
\hline \multirow{2}{*}{ Levin,Lin\&Chu } & $-5.76625^{*}$ & $-12.8085^{*}$ & $-13.2233^{*}$ & $(0.0000)$ \\
& $(0.0000)$ & $(0.0000)$ & $(0.0000)$ & $189.419^{*}$ \\
ADF - Fisher & $78.0238^{*}$ & $206.813^{*}$ & $214.319^{*}$ & $(0.0000)$ \\
& $(0.0001)$ & $(0.0000)$ & $(0.0000)$ & $220.634^{*}$ \\
PP - Fisher & $89.7964^{*}$ & $197.807^{*}$ & $203.868^{*}$ & $(0.0000)$ \\
\hline
\end{tabular}

* Gecikme uzunluğu SIC kriterine göre belirlenmiştir. Tüm testlerin boş hipotezi "birim kök vardır" şeklindedir. * ile işaretlenen değerler \% 1 anlamlılık düzeyinde istatistiksel açıdan anlamlıdır. ( ) ise olasılık değerini göstermektedir.

Tablo 2'deki test sonuçlarından da görüldüğü üzere tüm veriler, düzeyde bünyelerinde birim kök içermektedir. Nitekim gerek para arzı gerekse vergi hasılatına ilişkin verilerin durağan olmadıklarına ilişkin boş hipotez reddedilememektedir. Bunun yanında serilerin birinci düzey farkları I(1) alındığında ise her biri durağan hale gelmektedir. Serilerin düzeyde durağan olmadığı birinci düzeyde ise durağan hale geldiği belirlendikten sonra değişkenler arasında uzun dönemde eşbütünleşik bir ilişki olup olmadığı Johansen Fisher Eşbütünleşme Testi ile sınanmıştır. Eşbütünleşme testi sonuçları Tablo 3'te yer almaktadır.

Tablo 3: Johansen Fisher Panel Eşbütünleşme Testi Sonuçları

\begin{tabular}{|c|c|c|c|c|c|}
\hline & \multicolumn{3}{|c|}{ İz (Trace) Testi } & \multicolumn{2}{|c|}{ En Yüksek Özdeğer Testi } \\
\hline & Hipotezler & Fisher İstatistiği & $\begin{array}{l}\text { Olasılık } \\
\text { Değeri }\end{array}$ & $\begin{array}{l}\text { Fisher } \\
\text { İstatistiği }\end{array}$ & Olasılık Değeri \\
\hline \multirow{3}{*}{$\operatorname{lnM3}$ ile $\ln T V$} & Yok & $98.61 *$ & 0.0000 & $97.67 *$ & 0.0000 \\
\hline & & & & & \\
\hline & En fazla 1 & 32.09 & 0.7387 & 32.09 & 0.7387 \\
\hline \multirow{2}{*}{ InM3 ile InGAV } & Yok & $102.5^{*}$ & 0.0000 & $103.4 *$ & 0.0000 \\
\hline & En fazla 1 & 32.15 & 0.7361 & 32.15 & 0.7361 \\
\hline \multirow{2}{*}{ InM3 ile $\operatorname{lnHAV}$} & Yok & $90.29 *$ & 0.0000 & $90.22 *$ & 0.0000 \\
\hline & En fazla 1 & 32.83 & 0.7070 & 32.83 & 0.7070 \\
\hline
\end{tabular}

* ile işaretlenen değerler \% 1 anlamlılık düzeyinde istatistiksel açıdan anlamlıdır.

lnM3 ile lnTV serileri arasındaki ilişkileri irdeleyen test sonuçlarına göre iki değişken arasında eşbütünleşik ilişki olmadığına ilişkin boş hipotezin gerek İz (Trace) gerekse En Yüksek Özdeğer Testince \% 1 anlam düzeyinde reddedildiği, buna karşıllk seriler arasında en fazla bir eşbütünleşik ilişkinin olduğunu ileri süren boş hipotezin ise iki test tarafindan da reddedilemediği görülmektedir. Benzer sonuçlar lnM3 ile $\operatorname{lnGAV}$ ve $\operatorname{lnM} 3$ ile $\operatorname{lnHAV}$ arasındaki eşbütünleşik ilişkileri irdeleyen testlerce de ortaya konulmuştur. Bu kapsamda Tablo 3 'te yer 
alan test sonuçlarından para arzı değişkeni ile vergi hasılatı değişkenleri arasında uzun dönemli eşbütünleşik bir ilişki olduğu anlaşılmaktadır.

Tablo 4: Panel Vektör Hata Düzeltme Modeli ve Wald Testine İlişsin Sonuçlar

\begin{tabular}{|c|c|c|}
\hline Boş Hipotez & Wald Testi (Kısa Dönem) & VECM (Uzun Dönem [ECT]) \\
\hline \multirow{3}{*}{ Toplam Vergi => Para Arzı } & \multirow{3}{*}{2.848237} & $-0.025989 * *$ \\
\hline & & $(0.012290)$ \\
\hline & & {$[-2.114609]$} \\
\hline \multirow{3}{*}{ Para Arzı $=>$ Toplam Vergi } & \multirow{3}{*}{$10.82749 *$} & $-0.022155^{*}$ \\
\hline & & $(0.004260)$ \\
\hline & & {$[-5.201056]$} \\
\hline \multirow{3}{*}{$\begin{array}{l}\text { Gelir Üzerinden Alınan Vergiler }=> \\
\text { Para Arzı }\end{array}$} & \multirow{3}{*}{2.757678} & $-0.028615^{* *}$ \\
\hline & & $(0.012928)$ \\
\hline & & [-2.213406] \\
\hline \multirow{3}{*}{$\begin{array}{l}\text { Para Arzı }=>\text { Gelir Üzerinden Alınan } \\
\text { Vergiler }\end{array}$} & \multirow{3}{*}{$15.59890 *$} & $-0.019059 *$ \\
\hline & & $(0.003953)$ \\
\hline & & [-4.821680] \\
\hline \multirow{3}{*}{$\begin{array}{l}\text { Harcamalar Üzerinden Alınan Vergiler } \\
=>\text { Para Arzı }\end{array}$} & \multirow{3}{*}{2.779926} & $-0.022450 * * *$ \\
\hline & & $(0.013485)$ \\
\hline & & {$[-1.664796]$} \\
\hline \multirow{3}{*}{$\begin{array}{l}\text { Para Arzı }=>\text { Harcamalar Üzerinden } \\
\text { Alınan Vergiler }\end{array}$} & \multirow{3}{*}{$6.124831 * *$} & $-0.020047 *$ \\
\hline & & $(0.004130)$ \\
\hline & & {$[-4.854241]$} \\
\hline
\end{tabular}

*,**,***ile işaretlenen değerler sırasıyla $\% 1, \% 5$ ve $\% 10$ anlamlılık düzeyinde istatistiksel açıdan anlamlıdır. ( ) Standart hata, [ ] t istatistiği değerini göstermektedir.

Değişkenler arasında uzun dönemde eşbütünleşik bir ilişkinin varlığı saptandıktan sonra, serilerin uzun dönemli nedensellik ilişkilerini belirleyebilmek için Panel Vektör Hata Düzeltme Modelinden yararlanılmış olup, Tablo 4 elde edilen ampirik bulguları içermektedir. Vektör Hata Düzeltme Modellerinde "hata düzeltme terimi"nin (ECT) negatif ve istatistiksel açıdan anlamlı olması ele alınan değişkenler arasında uzun dönemli nedensellik ilişkisi olduğunu göstermektedir (Pesaran, Shin ve Smith, 2000). Buradan yola çıkarak Toplam Vergiden Para Arzına doğru \% 5, Para Arzından Toplam Vergiye doğru \% 1; Gelir Üzerinden Alınan Vergilerden Para Arzına doğru \% 5, Para Arzından Gelir Üzerinden Alınan Vergilere doğru \% 1; Harcamalar Üzerinden Alınan Vergilerden Para Arzına Doğru \% 10, Para Arzından Harcamalar Üzerinden Alınan Vergilere doğru \% 1 anlam düzeyinde istatistiksel olarak uzun dönemli bir nedensellik ilişkisi olduğu anlaşılmaktadır. Bu bulgular ayrıca tüm sistem için serilerin durağan olmamasından kaynaklanan kısa dönem sapmalarının yaklaşı \% 2,3'ünün bir sonraki dönemde düzeleceğini ve uzun dönem dengesine yaklaşacağını da göstermektedir. Değişkenler arasındaki kısa dönemli nedensellik ilişkilerini belirleyebilmek için yararlanılan Wald Testi sonuçları ise 
kısa dönemde para arzından toplam vergiye doğru \% 1, gelir üzerinden alınan vergilere doğru \% 1 ve harcamalar üzerinden alınan vergilere doğru \% 5 düzeyinde istatistiksel açıdan anlamlı bir nedensellik ilişkisi olduğunu ortaya koymaktadır.

Şekil 1, nedensellik analizi neticesinde elde edilen bulguları görsel olarak ortaya koymaktadır. Buradan uzun dönemde para arzı ve vergi hasılatı değişkenleri arasında çift yönlü bir nedensellik ilişkisinin olduğu görülmektedir. Kısa dönemde ise ilişkinin sadece para arzından vergi hasılatı değişkenlerine doğru olduğu gözlemlenmektedir.

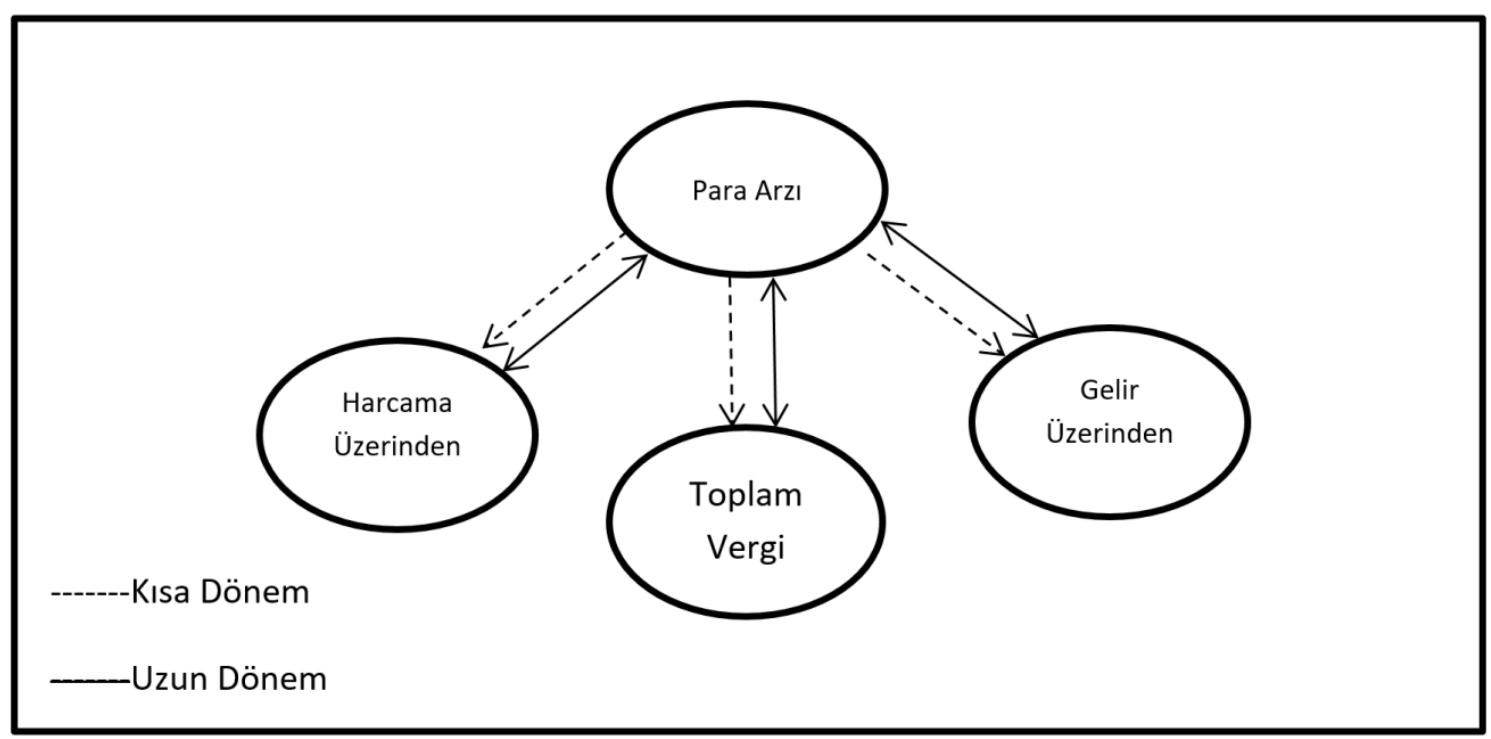

Şekil 1: Para Arzı-Vergi Hasılatı İlişkisi

\section{SONUÇ}

Paranın ne olduğu ve nasıl yaratıldığı üzerine yapılan tartışmalar, para yaratılma sürecinde neyin etkili olduğu üzerine odaklanır. Bu tartışmalarda Metalist Yaklaşım, paranın doğal olarak değiş-tokuş işlemi sırasında ortaya çıktığını iddia eder. Dolayısıyla para nötrdür ve hiçbir toplumsal ilişkiye bağlı değildir. Kartalist Yaklaşım ise paranın nötr olmadığını, siyasal ve toplumsal yapı ile yakın bir ilişki içerisinde olduğunu savunur. Bundan dolayı paranın yaratılmasında ve ne olduğunun belirlenmesinde en önemli rol, devletin ve devletin topladığı vergilerin üzerindedir. Bunun için de harcamalarını finanse etmeye çalışan devletin topladığ vergiler ve para arzı arasında birbirini etkileyen bir ilişki söz konusudur. Bu ilişkide vatandaşlar paranın yaratılmasında vergilerini ödeyerek sorumluluk üstlenirken, para yaratıcı kurumların (Merkez Bankası) pasifleşmesine neden olur. Geleceği ön görmeye çalışan bireyler, siyasal otoritenin para politikalarını değil vergi politikalarını dikkate almaya başlar.

$\mathrm{Bu}$ çalışmada Kartalist Yaklaşım çerçevesinde para arzı ile vergiler arasındaki kısa ve uzun dönemli nedensellik ilişsileri Vektör Hata Düzeltme Modeli ile incelenmiştir. Analiz sürecinde 19 OECD üyesinin 1996-2015 yılları arasındaki para arzı (M3) ile vergi hasılatı (toplam, gelir üzerinden alınan, harcamalar üzerinden alınan) verileri esas alınmıştır. Elde edilen ampirik bulgulara göre kısa dönemde para arzından vergi hasılatı değişkenlerine doğru tek yönlü bir nedensellik ilişkisi tespit edilmiştir. Uzun dönemde ise para arzı ve vergi hasılatı değişkenleri arasında çift yönlü bir etkileşim vardır. Dolayısıyla uzun dönemde para arzı vergi hasılatını etkilemekte ve etkilenmektedir. 
$\mathrm{Bu}$ sonuçlar uzun dönemde paranın sosyal bir sözleşmeye dayalı ve vergiler tarafından yaratıldığını desteklemektedir. Diğer bir ifadeyle, tedavüle sokulan para miktarı, vergi hasılatı ile eşdeğer nitelik göstermektedir. Devlet, vergiler yoluyla neyin para olduğunu belirlerken, vergi hasılatıyla para arzı üzerinde de etkili olmaktadır. Bununla birlikte bireyler, hesap birimi olan parayı devlete yükümlülüklerini yerine getirmesi için iade ederken, para arzı üzerinde de etkin rol oynamış olurlar. Böylece para, nötr olma özelliğini yitirir. Sosyal sözleşmenin bir yansitıcısı olur.

Diğer taraftan para arzı ile vergi hasılatı değişkenleri arasında uzun dönemde çift yönlü bir nedensellik ilişkisinin varlığı, Kartalist Yaklaşımın temel argümanlarını destekler niteliktedir. Kısa dönemde bireyler para arzının genişlemesini fark edememekte, uzun dönemde ise beklentilerini devreye sokarak ve rasyonel hareket ederek para arzının miktarını ödedikleri vergilerle etkilemektedir. Bu ise vergi hasılatı kadar paranın arz edilmesi gerektiğini savunan Kartalist Yaklaşımın düşüncesini destelemektedir. Diğer bir ifadeyle, ekonomi politikasında bireyler, devletin almış olduğu vergi politikası kararlarını da rasyonel şekilde takip etmektedir. Uzun dönemli politikalar açısından, devletler vergi gelirleri ile para arzını da etkilemiş olmaktadir.

\section{KAYNAKÇA}

Amable, B. (2011). Moral and Politics in the Ideology of Neoliberalism. Socio-Economic Review, 51 (1): 46-55.

Anderson, B. (2011). Hayali Cemaatler Milliyetçiliğin Kökenleri ve Yayılması. Çeviren: Savaşır, E. Metis Yayınları. İstanbul.

Barro, R. J. \& Gordon D. B. (1983). Rules, Discretion and Reputation in a Model of Monetary Policy. Journal of Monetary Economics, 12(1): 101-121.

Bell, S. \& Henry, J.F. (2001). Hospitality versus Exchange: The Limits of Monetary Economics, Review of Social Economy, 59 (2): 203-226.

Bordo, M. \& James, H. (2006). One World Money, Then and Now, NBER Working Paper Series .

Centeno, M.A. \& Cohen, J. N. (2010). Global Capitalism: A Sociological Perspective. MA: Polity.

Centeno, M.A. \& Cohen, J. N. (2012). The Arc of Neolberalism. Annual Review of Sociology. Vol: 38. s.s. 317-340.

Cesarano, F. (1995). The New Monetary Economics and The Theory of Money, Journal of Economic Behavior and Organization, 26: 445-455.

Choi, I. (2001). Unit Root Tests for Panel Data, Journal of International Money and Finance, 20: 249-272.

Frisby, D. (2005). Georg Simmel Modernitenin İlk Sosyoloğu. G. Simmel Modern Kültürde Çatışma. Çev: Gen, E.. İletişim Yayınları. İstanbul. s. 7-53.

Gnos, C. \& Rochon, L.P. (2002). Money Creation and The State A Critical Assessment of Chartalism, International Journal of Political Economy, 32 (3): 41-57.

Goodhart, C.A. (1998). The Two Concepts of Money: Implications for The Analysis of Optimal Currency Areas, European Journal of Political Economy, 14: 407-432.

Gwartney, J. D., Hall, J, \& Lawson, R. (2010). Economic Freedom of the World: 2010 Annual Report. Frasier Institute. Vancouver.

Hobsbawm, E. J. \& Ranger, T. (2006). Geleneğin İcadı. Çeviren: Şahin, M. M., Agora Kitaplığı. İstanbul.

Hudson, M. (2004). The Archaeology of Money: Debt Versus Barter Theories of Money's Origins. L. R. Wray içinde, Credit and State Theories of Money: The Contributions of A. Mitchell Innes (s. 99-127), Cheltenham, UK, Edward Elgar.

Maddala, G. S. \& Wu, S. (1999). A Comparative Study of Unit Root Tests with Panel Data and A New Simple Test, Oxford Bulletin of Economics and Statistics, 61: 631-652.

Miller, T. \& Holmes, K. R. (2011). 2011 Index of Freedom. Heritage Foundation. Washington. 
Ingham, G. (2000). Babylonian Madness: On The Historical and Sociological Origins of Money, J. Smithin içinde, What is Money? (s. 16-41), London and New York: Routledge.

Johansen, S. (1988). Statistical Analysis of Cointegration Vectors, Journal of Economic Dynamics and Control, 12 (23): $231-254$.

Jung, W. (1995). Georg Simmel: Yaşamı, Sosyolojisi, Felsefesi. Çev: Özlem, D. Ark Yayınevi. Ankara.

Keyder, Ç. (2009). Türkiye'de Devlet ve Sınıflar. İletişim Yayınları. İstanbul.

Keynes, J.M. (2012). Para Üzerine Bir İnceleme, (Çev.) GERÇEK, C., İstanbul, Türkiye İş Bankası Kültür Yayınları Hasan Âli Yücel Klasikler Dizisi.

Knapp, G.F. (1924). The State Theory of Money. Clifton, NY: Augustus M. Kelley.

Kuhn, T. S. (2008). Bilimsel Devrimlerin Yapısı, Çeviren: Kuyaş, N., Kırmızı Yayınları. İstanbul.

Kydland, F. E. \& Prescott, E. C. (1977). Rules rather than Discretion: The Inconsistency of Optimal Plans. The Journal of Political Economy. 85 (3): 479-492.

Menger, C. (2009). İktisadın Prensipleri, (Çev.) ÇELEBİ, A.K., Ankara, Liberte Yayınları.

Neale, W.C. (1976). Monies in Societies, San Francisco, Chandler \& Sharp.

OECD (2017), Broad money (M3) (indicator). doi: 10.1787/1036a2cf-en (Erişim: 23 Mart 2017)

OECD (2017), Tax revenue (indicator). doi: 10.1787/d98b8cf5-en (Erişim: 23 Mart 2017)

OECD (2017), Tax on personal income (indicator). doi: 10.1787/94af18d7-en (Erişim: 23 Mart 2017)

OECD (2017), Tax on corporate profits (indicator). doi: 10.1787/d30cc412-en (Erişim: 23 Mart 2017)

OECD (2017), Tax on goods and services (indicator). doi: 10.1787/40b85101-en (Erişim: 23 Mart 2017)

Peacock, M.S. (2003). State, Money, Catallaxy: Underlaboring for A Chartalist Theory of Money, Journal of Post Keynesian Economics, 26(2): 205-225.

Pesaran, M.H. \& Shin, Y. \& R. Smith (2000). Structural Analysis of VECMs with Exogenous I(1) Variables, Journal of Econometrics, 97 (2): 293-343.

Schumpeter, J.A. (1954). History of Economic Analysis, Oxford, Oxford University Press.

Schumpeter, J. A. (2008). Capitalism, Socialism and Democracy, Harper Perennial Modern Thought Edition. New York.

Tönnies, F. (2000). Gemeinschaft ve Gesellschaft, Şehir ve Cemiyet: Weber, Tönnies ve Simmel içinde, Çev: Aydoğan, A. s.s 185-217. İz Yayınc1lık. İstanbul.

Wray, L.R. (2012). Introduction to an Alternative History of Money, New York, Levy Economics Institute of Bard College.

Wray, L.R. (2002). State Money, International Journal of Political Economy, 32 (3): 23-40.

Yılmaz, R. \& Çelikay, F. (2017). Türkiye'de Paranın Yaratılmasında Vergilerin Rolünün Kartalist Yaklaşım Çerçevesinde Değerlendirilmesi. Süleyman Demirel Üniversitesi İktisadi ve İdari Bilimler Dergisi, 22 (2)'de yayımlanmak üzere kabul edilen makale.

Zelizer, V.A. (1989). The Social Meaning of Money: Special Money, American Journal of Sociology, 95 (2): $342-$ 377. 